\title{
Welding of Thermally Modified Wood and Thermal Modification of the Welded Wood: Effects on the Shear Strength under Climatic Conditions
}

\begin{abstract}
Mojgan Vaziri,* and Dick Sandberg
This work investigated how thermal modification affects the shear strength of welded joints under different climatic conditions. The order of the thermal modification, before or after the welding, was investigated for its effect on the shear strength of the welded wood. Two groups of thermally modified specimens were prepared in a laboratory kiln under controlled conditions, one thermally modified before welding and the other after welding of the specimens. The shear strength of the specimens were measured at four different moisture contents of $10 \%, 12 \%, 16 \%$, and $18 \%$, and the results for the two different approaches were compared. Moreover, observations of the X-ray computed tomography scanning and digital microscopy were used to study the density profile and the structural details of the welded joints. The results showed that thermal treatment of the wood either before or after welding had a negative influence on the shear strength, and the modes of failure of the joints in mechanical tests were in most cases brittle. In the weld interface of the wood modified before welding, a rigid material similar to charcoal was produced as a result of the further degradation of wood by welding pressure and frictional motion. Welding of wood before thermal modification, however, yielded thicker and more densified joints with less susceptibility to higher moisture variations than the joints obtained by welding the thermally modified wood.
\end{abstract}

Keywords: CT scanning; Digital microscopy; Shear strength; Thermal modification; ThermoWood

Contact information: Luleå University of Technology (LTU), Wood Science and Engineering, Forskargatan 1, 931 87, Skellefteå, Sweden; *Corresponding author: Mojgan.vaziri@ltu.se

\section{INTRODUCTION}

In the beginning of the $20^{\text {th }}$ century, heat and moisture (thermo-hydro $(\mathrm{TH})$ techniques) were introduced to wood processing. Wood dried at a high temperature changes color and has greater dimensional stability and lower hygroscopicity than untreated wood (Tiemann 1906; Stamm 1964; Sandberg and Kutnar 2016). Thermal modification can be an alternative for decreasing the hygroscopicity of the welded wood instead of using toxic chemicals, which defeat the purpose of having an environmentally friendly bonding.

Wood welding is an environmentally compatible assembling and manufacturing process that has a remarkable potential as an alternative to synthetic adhesives in timber engineering. The adhesion mechanism of welded wood is based on the softening and flowing of some amorphous, cells-interconnecting polymer material, mainly lignin and hemicelluloses (Gfeller et al. 2003). However, there have been few studies related to structural applications, which is partially due to the vulnerability of the welded joint to damage from moisture. Therefore, welded wood cannot be used based merely on its acceptable mechanical resistance; rather, its hygroscopicity and mechanical behavior must 
be considered in a coupled manner. One hypothesis that could explain the poor waterresistance of the welded joints is that uneven swelling of the welded interface and of the adjacent wood causes severe stresses that crack and open the welded joints (Vaziri et al. 2019). The objective of this work was to study the influence of thermal modification, before or after vibration welding, on the resistance of the welded joints to varying humidity. Among the wood constituents, hemicellulose is the most degradable and lignin is the most stable polymer during thermal treatment. The chemical structure of the lignin is altered through the demethoxylation of ether bonds, auto-condensation reactions, and crosslinking, which leads to a reduction in water absorption of the wood due to the decrease in the number of free hydroxyl group. On the other hand, degradation of polysaccharides significantly reduce the mechanical properties of wood such as flexural and tensile strength (Stamm 1956; Esteves et al. 2006; Živković et al. 2008; Mahnert et al. 2013). Considering the improved properties of thermally modified wood, it would be interesting to figure out how thermal modification could influence the shear strength of the welded wood, and whether it makes a difference whether the welding is done before or after the thermal modification.

Currently, there is no report on the effect of thermal modification after vibration welding (W-TH) on the shear strength. Despite many advances in thermal degradation of wood, few studies have been done on the thermal modification of welded wood, and many questions remain unanswered. Moreover, there is a lack of consensus on the reported results regarding the welding of thermally modified wood (TH-W), and both an increase and decrease in the shear strength are reported (Boonstra et al. 2006; Omrani et al. 2010; Zigon et al. 2015). Most studies consider the welding of hardwoods.

The thermal modification method used in this study is based on the industrial ThermoWood principles developed at the Finnish Research Center VTT (Jämsä and Viitaniemi 2001). ThermoWood is the most widely used industrial thermal modification process that has been improving progressively (ThermoWood 2019). The present study examined the effect of thermal modification on the shear strength of the welded joint in a moist environment. Using non-destructive test methods such as X-ray computed tomography (CT-scanning) and digital microscopy, the density and structural details of the welded joints were studied.

\section{EXPERIMENTAL}

\section{Preparation of Specimens}

Four sets of the specimens were prepared: specimens welded before thermal modification (W-TH), specimens welded after thermal modification (TH-W), and their respective controls. The control specimens were prepared from non-treated wood welded with high pressure (control $\mathrm{W}-\mathrm{TH}$ ) and low pressure (control $\mathrm{TH}-\mathrm{W}$ ) according to the Table 1. The specimens were prepared from wood specimens with planed surfaces and dimensions of $20 \mathrm{~mm} \times 20 \mathrm{~mm} \times 230 \mathrm{~mm}(\operatorname{radial}(\mathrm{R}) \times$ tangential $(\mathrm{T}) \times$ longitudinal $(\mathrm{L}))$ from clear pieces of Scots pine sapwood (Pinus sylvestris L.), grown in Skellefteå in the north of Sweden.

The specimens and their respective controls were conditioned for two weeks at 20 ${ }^{\circ} \mathrm{C}$ and $65 \%$ relative humidity $(\mathrm{RH})$ in an environmental chamber to $12 \%$ average moisture content (MC). They were welded together in pairs to dimensions of $20 \mathrm{~mm} \times 40 \mathrm{~mm} \times 230$ $\mathrm{mm}$ (along the end-grain-to-end-grain of the radial face-to-radial face) using a linear 
vibration welding machine, Branson model M-624 (Branson Ultraschall, Dietzenbach, Germany) with a frequency of $240 \mathrm{~Hz}$ and settings according to Table 1 . The TH-W specimens were prepared from wood pieces of the same quality as the W-TH specimens, but were thermally modified prior to welding.

The most influential welding parameters shown in Table 1 were selected based on earlier studies (Vaziri et al. 2012, 2020). The appropriate range of parameters that could result in the maximum shear strength of the welded joints was defined by a screening test. Notwithstanding the earlier studies (Gfeller et al. 2003; Boonstra et al. 2006), using a longer welding time and/or higher pressure for the welding of thermally modified wood caused severe degradation of the wood and delamination of the welded joint just after welding. Thus, the pressures and welding times needed to be less extreme than the conditions of welding optimized for non-treated wood. Hence, two sets of control specimens with different welding pressures were prepared.

Table 1. Welding Procedure and Classification of the Specimens

\begin{tabular}{|c|c|c|c|c|c|}
\hline Welded Specimens & $\begin{array}{c}\text { Welding } \\
\text { Times } \\
\text { S1+S2 (s) }\end{array}$ & $\begin{array}{c}\text { Holding } \\
\text { Time } \\
(\mathrm{s})\end{array}$ & $\begin{array}{c}\text { Initial } \\
\text { Welding } \\
\text { Pressure } \\
\text { (MPa) }\end{array}$ & $\begin{array}{c}\text { Second } \\
\text { Welding } \\
\text { Pressure } \\
\text { (MPa) }\end{array}$ & $\begin{array}{c}\text { Holding } \\
\text { Pressure } \\
\text { (MPa) }\end{array}$ \\
\hline W-TH & $2.5+3$ & 10 & 2 & 2.7 & 2.7 \\
\hline Control - W-TH & $2.5+3$ & 10 & 2 & 2.7 & 2.7 \\
\hline TH-W & $2.5+3$ & 10 & 1.4 & 2 & 2.7 \\
\hline Control - TH-W & $2.5+3$ & 10 & 1.4 & 2 & 2.7 \\
\hline
\end{tabular}

\section{Thermal Modification}

The specimens were dried at room temperature to $8 \%$ average $\mathrm{MC}$ and were then moved to a laboratory conditioning kiln where the initial climate was $70{ }^{\circ} \mathrm{C}$ for a dry bulb and $55{ }^{\circ} \mathrm{C}$ for a wet bulb. The thermal modification process was performed according to the principles of the ThermoWood process (Finnish ThermoWood Association 2003) as shown in Fig. 1.

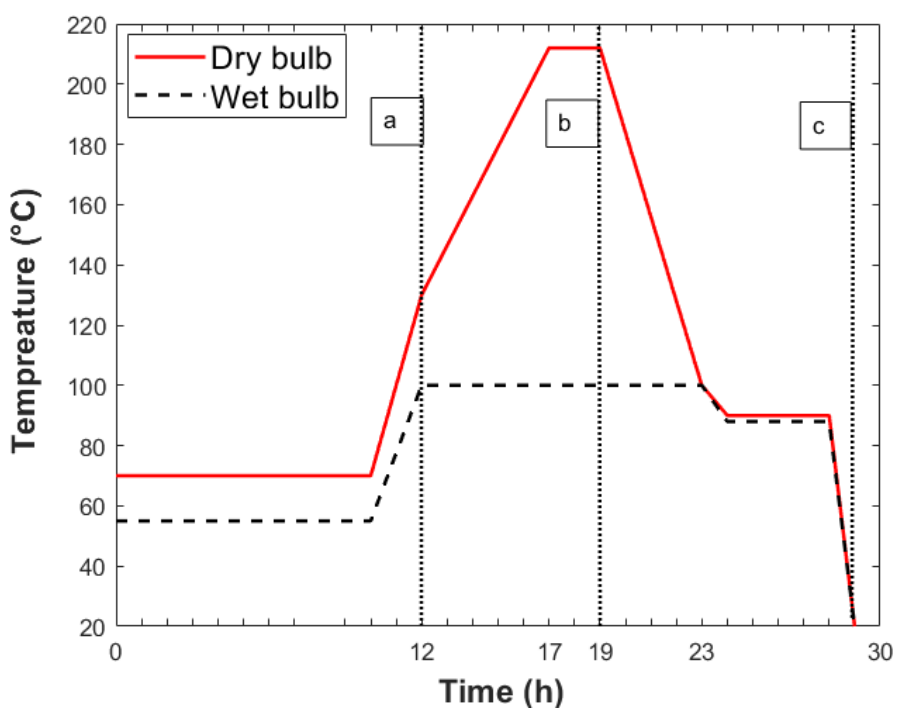

Fig. 1. Schedule of thermal modification, with the three phases of (a) drying, (b) heat treatment, and (c) cooling and moisture conditioning 
The process can be divided into three main phases: (a) drying, (b) heat treatment, and (c) cooling and moisture conditioning. The drying process ended with a fast increase of kiln temperature to $130{ }^{\circ} \mathrm{C}$ in the dry bulb and $100{ }^{\circ} \mathrm{C}$ in the wet bulb to dry the wood to nearly $0 \% \mathrm{MC}$. The heat transferring media was superheated steam with oxygen less than $35 \%$. The thermal modification step included increasing and holding the temperature in dry bulb at $212{ }^{\circ} \mathrm{C}$ for $2 \mathrm{~h}$ while the temperature in wet bulb was $100^{\circ} \mathrm{C}$. The kiln was then cooled down from $212{ }^{\circ} \mathrm{C}$ to $100{ }^{\circ} \mathrm{C}$ for $4 \mathrm{~h}$ and then to $90{ }^{\circ} \mathrm{C}$ in dry bulb and $88^{\circ} \mathrm{C}$ in the wet bulb during the following hour. The temperature was held at $90{ }^{\circ} \mathrm{C}$ and $88{ }^{\circ} \mathrm{C}$ for $4 \mathrm{~h}$ with high $\mathrm{RH}$ followed by another $1 \mathrm{~h}$ of cooling down to $20^{\circ} \mathrm{C}$.

\section{Mechanical Test}

The welded specimens were cut according to the EN 205 (2003) standard. Two cuts with a distance of $10 \mathrm{~mm}$ were made in the middle of the specimens, perpendicular to the welded joint. The specimens were formed in a way that was appropriate for the test equipment (Vaziri et al. 2012). Forty specimens of each type were conditioned in four different environmental chambers for approximately 3 weeks to reach average moisture contents of $10 \%\left(20^{\circ} \mathrm{C}\right.$ and $\left.55 \% \mathrm{RH}\right), 12 \%\left(20{ }^{\circ} \mathrm{C}\right.$ and $\left.65 \% \mathrm{RH}\right), 16 \%\left(20{ }^{\circ} \mathrm{C}\right.$ and $78 \%$ $\mathrm{RH})$, and $18 \%\left(20^{\circ} \mathrm{C}\right.$ and $\left.83 \% \mathrm{RH}\right)$. The specimens were tested on a tensile-shear strength test machine (Hounsfield, model H1KS, Redhill, UK), along the longitudinal direction of the samples, in the direction of the wood fibers and at a rate of $2 \mathrm{~mm} / \mathrm{min}$. Fisher's LSD (Least Significant Difference) method was used in ANOVA to create a multiple range test with the $95 \%$ confidence intervals for all pairwise differences between shear strength results.

\section{Digital Microscopy}

A DSX1000 digital microscope (Olympus, Essex, UK) was used to see the fine structural details in the samples with high resolution. The weld lines were observed from different angles using a tilting frame and motorized XY stage with up to $90^{\circ}$ rotation. The welded joints of the specimens were opened with a steel chisel, carefully cleaned with hexane before each use, and the weld interface was examined with a telocentric optical system. Three replicates of each type of the specimens were studied.

\section{CT Scanning}

Small samples with dimensions of $20 \mathrm{~mm} \times 40 \mathrm{~mm} \times 50 \mathrm{~mm}$ (radial $(\mathrm{R}) \times$ tangential $(\mathrm{T}) \times$ longitudinal $(\mathrm{L}))$ were prepared from the welded specimens. The specimens were conditioned at room ambient conditions for two weeks to $8 \%$ average MC before they were scanned. For each type of specimen (W-TH and TH-W) and the respective controls, five replicates were scanned. In total 20 specimens were prepared. The specimens were scanned by a medical X-ray CT scanner (Siemens Emotion Duo; Siemens Healthcare GmbH, Erlangen, Germany) at ambient conditions with the settings listed in Table 2. The standard algorithm of the Shepp-Logan kernel was used for the image reconstructions (Shepp and Logan 1974). The specimens were scanned ten times on their cross section at a distance interval of $2 \mathrm{~mm}$ along the welded joint. The CT-numbers were averaged using the software Matlab® R2018b (The MathWorks, Inc., Natick, MA, USA) as shown in Fig. 2. The average CT image of each specimen was obtained by averaging ten $2 \mathrm{~mm}$-distanced slices in the z-axis direction. The X-ray absorption was measured along a line of 100 pixels across the weld line, as shown with a black line in this figure and as the CT-number profiles in Fig. 4. 


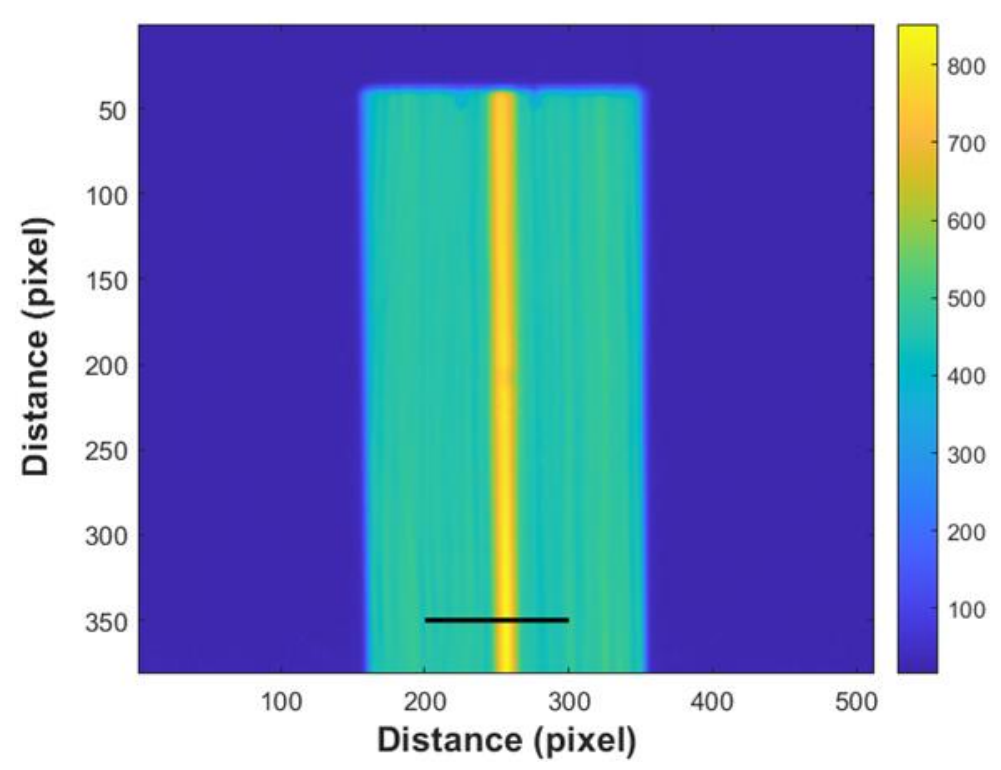

Fig. 2. An example of the average CT image taken over the five specimens (replicates) that had been heat treated after welding (W-TH). The color scale on the right hand shows the corresponding CT-numbers. The line is positioned on the 350 pixel-height in the $y$-axis direction and between pixels 200 and 300 in the $x$-axis direction

Table 2. Settings of the CT Scanner

\begin{tabular}{|c|c|c|}
\hline Parameter & Unit & Value \\
\hline Voltage & $\mathrm{kV}$ & 110 \\
\hline Current & $\mathrm{mA}$ & 70 \\
\hline Scan time & $\mathrm{s}$ & 2 \\
\hline Scan thickness & $\mathrm{mm}$ & 5 \\
\hline Matrix & Pixels & $512 \times 512 \times 10$ \\
\hline Resolution & Pixels/mm & 2.3 \\
\hline $\begin{array}{c}\text { Number of scans (in the z-axis } \\
\text { direction) }\end{array}$ & & 10 \\
\hline
\end{tabular}

\section{RESULTS AND DISCUSSION}

Figure 3 shows the results of the shear strength tests. The thermal treatment had a negative effect on the shear strength of the welded joints, and the mode of failure of thermally modified wood in mechanical tests was in most cases brittle. This result was indicated by a significant reduction in shear strength of the thermally modified specimens in comparison to non-treated control specimens. This result is in line with a previous study (Boonstra et al. 2006) that showed that thermal modification of wood based on an industrial two-step Plato process markedly reduced the shear strength of the joint. The joint strength was, however, markedly lower than that obtained when welding non-modified timber. The loss in strength is generally due to a degradation of the hemicellulose polymer, which results in the degradation of the cell-wall matrix (Kollmann and Fengel 1965). 


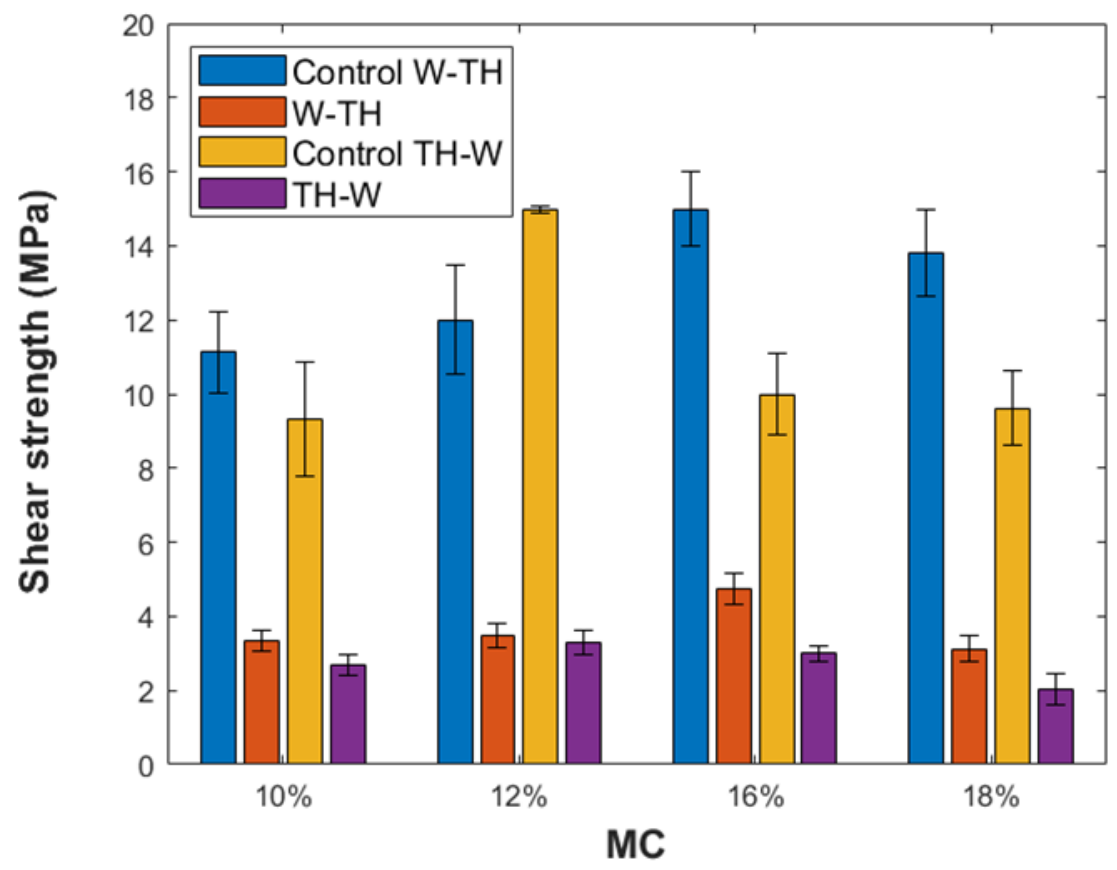

Fig. 3. Average shear strength of the specimens welded before thermal modification (W-TH), welded after heat treatment (TH-W), and non-treated welded controls (control W-TH, control THW) at four different MC levels

The average shear strength of the specimens welded before the thermal modification (W-TH) was greater than that of the specimens welded after thermal modification (TH-W). However, the multiple range test with the 95\% LSD (Least Significant Difference) procedure indicated that these differences were not statistically significant. Increasing the moisture content from 10 to $18 \%$ resulted in an insignificant decrease in the shear strength of the specimens that were thermally modified before welding $(\mathrm{TH}-\mathrm{W})$. The $\mathrm{W}-\mathrm{TH}$ specimens were less susceptible to humidity changes than $\mathrm{TH}-\mathrm{W}$ in the range of 10 to $18 \% \mathrm{MC}$.

Figure 4 shows the CT-number profile of two groups of specimens: those welded before and after thermal modification, and their respective non-treated controls. The average CT-image was taken over the five replicates of each group in the $\mathrm{z}$-axis direction and over all the 10 slices, which were distanced $2 \mathrm{~mm}$ from each other. The X-ray absorption was measured along a line of 100 pixels across the weld line, as is shown in Figure 2. Welding wood before thermal modification (W-TH) yielded thicker and more densified joints than those obtained by welding thermally modified wood (TH-W), and the average density of the welded joints in W-TH and TH-W samples were $89 \%$ and $24 \%$ greater than that of the adjacent wood, respectively. Thus, thermal modification affected the main melting region of the wood, namely the intercellular material. The thermallymodified wood materials had undergone chemical reactions so that inadequate material remained in the welding interface to build a strong welding joint (Boonstra et al. 2006).

Figure 5 shows microstructural differences between the non-treated (Fig. 5a) and thermally modified wood (Fig. 5b). The effect of the thermal modification became evident by a visible dark discoloration of the treated wood. Figure $5 \mathrm{c}$ and $5 \mathrm{~d}$ show the microstructure of the welded interface in non-treated control specimens. The wood fibers were torn out, destroyed, and crushed by high welding pressure so that the wood lost its 
original cellular structure (Fig. 5c). Using lower welding pressure, however, the wood cells were only partially destroyed and traces of unaffected wood were seen next to the welded wood (Fig. 5d). This could be one of the reasons for the lower strength obtained in welding non-treated wood at low pressure (control $\mathrm{TH}-\mathrm{W}$ ) than that obtained in welding non-treated wood at high pressure (control W-TH).
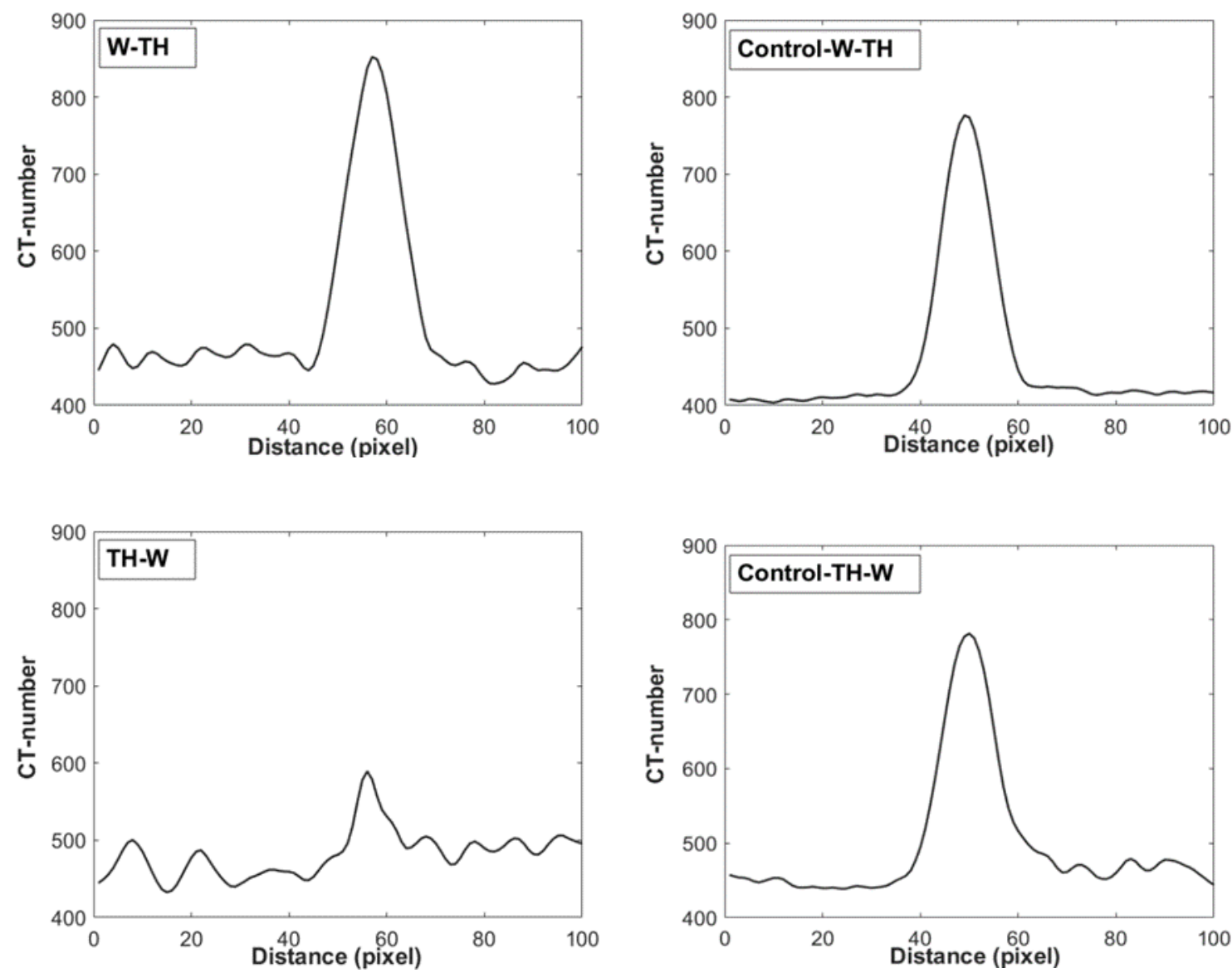

Fig. 4. Average CT-number profiles of four groups of specimens: welded before thermal modification $(\mathrm{W}-\mathrm{TH})$, welded after thermal modification (TH-W), and non-treated welded controls (control W-TH, control TH-W).

The softening or glass transition $\left(T_{\mathrm{g}}\right)$ of three major compounds of wood (Lignin, cellulose, hemicellulose) occurs at rather high temperatures. The glass transition for dry lignin and hemicellulose are around 124 to $235{ }^{\circ} \mathrm{C}$ and 167 to $217{ }^{\circ} \mathrm{C}$ respectively, but these values are highly related to the moisture content. Moist samples showed significantly lower softening temperatures, which averaged out at 78 to $128{ }^{\circ} \mathrm{C}$ for lignin and 54 to 142 ${ }^{\circ} \mathrm{C}$ for hemicellulose (Goring 1963; Horvath et al. 2011). According to the examinations of Gfeller et al. (2003), the temperature during welding exceeds the glass transition point of lignin and hemicelluloses. The presence of moisture and suitable heat during the welding and thermal modification can lead to softening and flowing of wood compounds mainly lignin. 
Figure 5e and 5f show the welded interface of thermally modified specimens (TH-W and W-TH). During welding of the thermally modified wood (TH-W) the contact zone is exposed to further decomposition due to the welding pressure, and frictional motion and rigid products similar to charcoal are produced (Fig. 5e). Figure $5 \mathrm{~h}$ shows the welded joint of the W-TH specimen in which a gap appeared. Thermohydro treatment of the welded wood may have caused softening and loss of the material that forms the interfacial welded composite and resulted in a gap in the welded joints.

The thinner welded joints in the TH-W specimens compared with the W-TH specimens were visible in microscopy images as well as in CT-number profiles in Fig. 4. This may indicate that due to the rigidity of the thermally modified wood, the cells were not detached and were not entangled as normally observed when welding non-treated timber and hence the interfacial strength was lower.

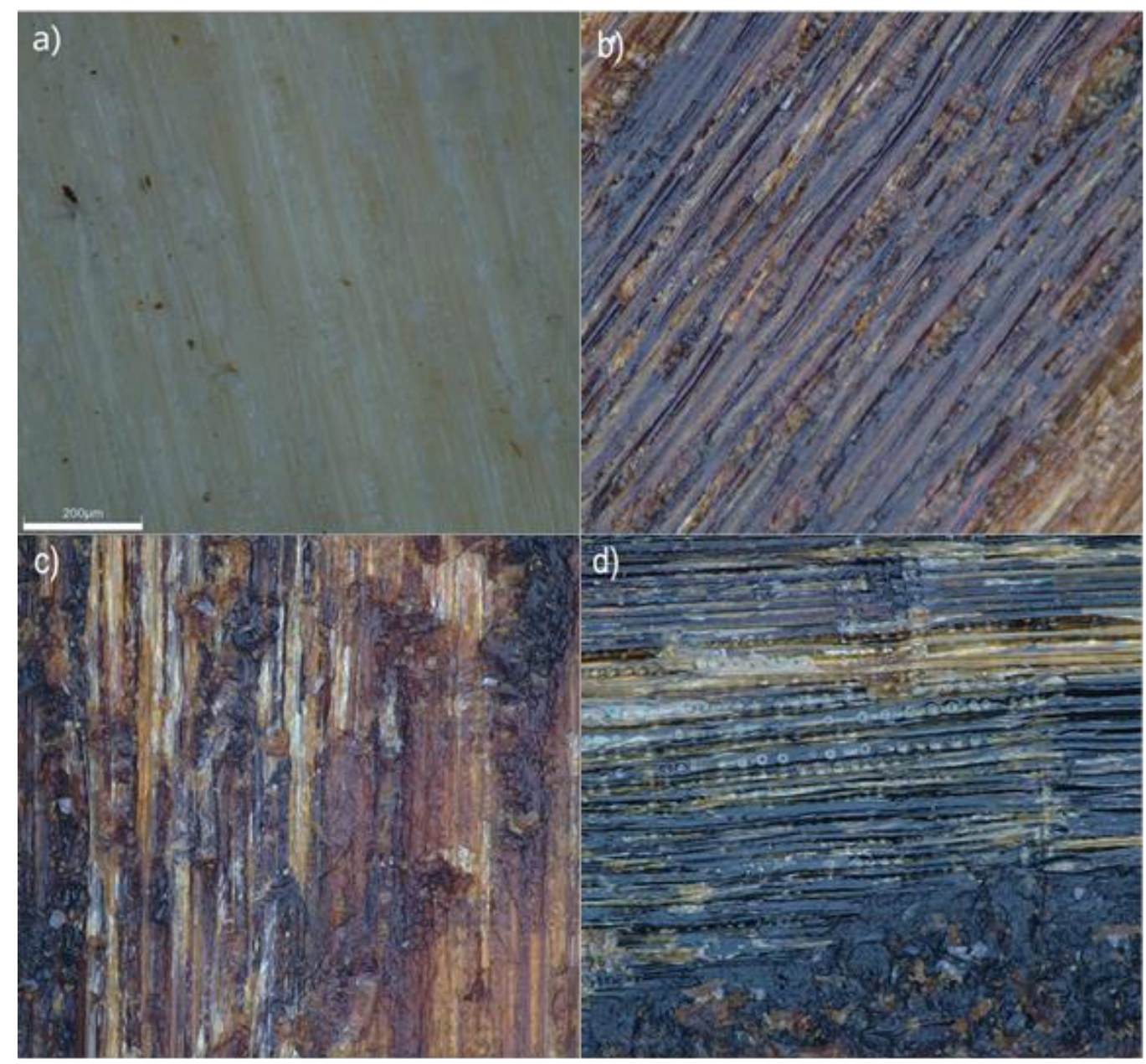



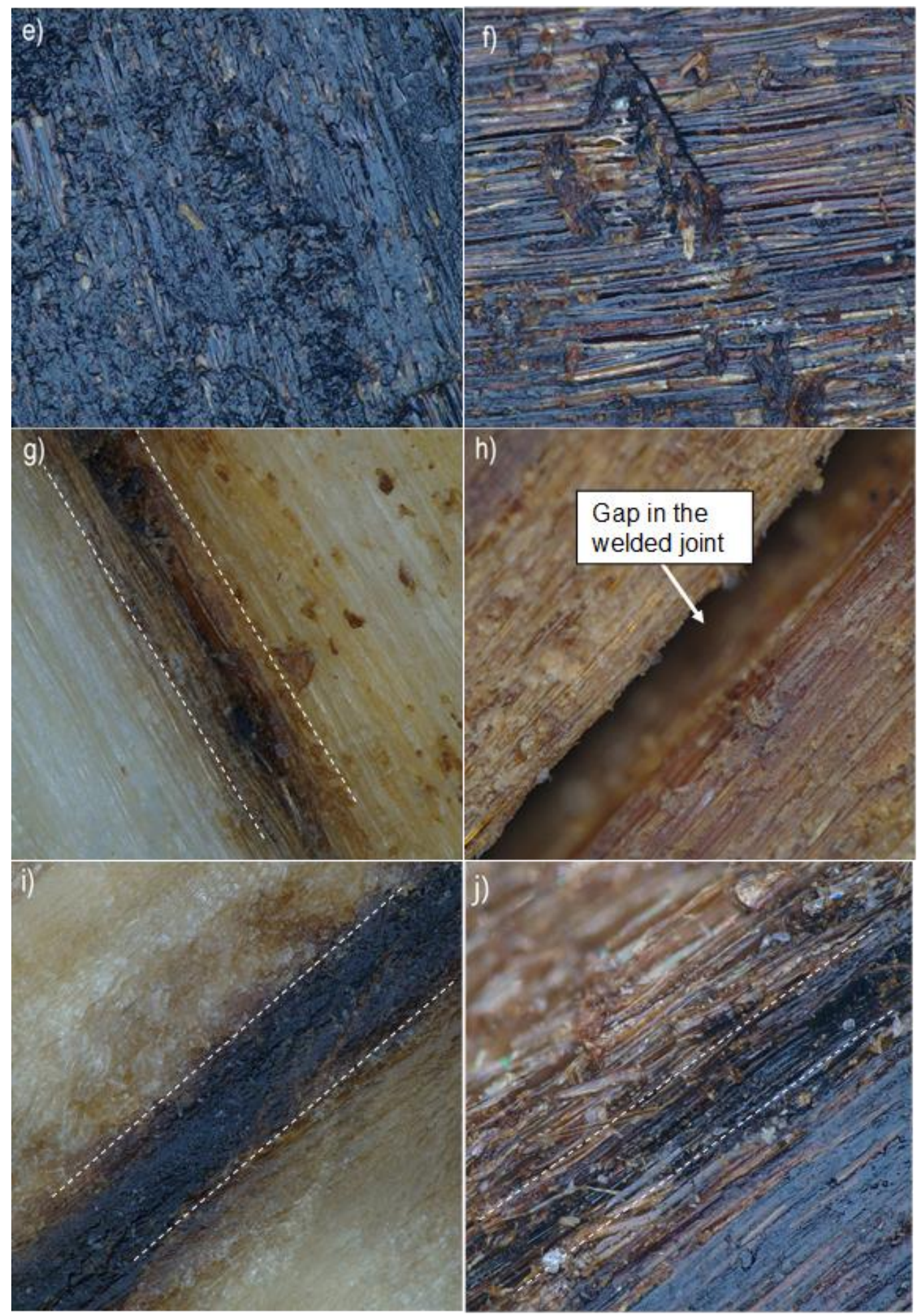

Fig. 5. Digital microscopy images of the thermally modified and non-treated specimens: a) nontreated pine sapwood, b) thermally modified pine sapwood, c) welded interface of control W-TH, d) welded interface of control TH-W, e) welded interface of TH-W, f) welded interface of $\mathrm{W}-\mathrm{TH}, \mathrm{g}$ ) welded joint of control $\mathrm{W}-\mathrm{TH}, \mathrm{h}$ ) welded joint of $\mathrm{W}-\mathrm{TH}$, i) welded joint of control TH-W, and j) welded joint of TH-W. The welded joint are marked with dotted lines in Figs. g, i, and j. All the images have the same scale as Fig. a $(200 \mu \mathrm{m})$. 


\section{CONCLUSIONS}

1. The shear strength of the thermally modified specimens was significantly lower than that of the respective control untreated specimens.

2. The shear strength of the welded joints were lower if thermal modification was done before welding rather than after welding. In vibration welding, the contact zone is exposed to welding pressure and frictional motion. For already thermally modified wood, this will lead to further decomposition and degradation of the wood and produce rigid chemical products similar to charcoal. This can be one of the reasons causing the lower shear strength of this type of welded joints (TH-W).

3. Thermal modification is not a suitable approach to improve the resistance of welded wood to water due to the considerable reduction in shear strength.

\section{ACKNOWLEDGMENTS}

Financial support from the Swedish Research Council for Environment, Agricultural Sciences and Spatial Planning (FORMAS), project Wood Welding - "Gluefree Wood Assembly 2017-01157", is gratefully acknowledged. The authors thank Dr. Mustafa Zor for laboratory support.

\section{REFERENCES CITED}

Boonstra, M., Pizzi, A., Ganne-Chedeville, C., Properzi, M., Leban, J. M., and Pichelin, F. (2006). "Vibration welding of heat-treated wood," J. Adhesion Sci. Technol. 20(4), 359-369. DOI: $10.1163 / 156856106776381758$.

EN 205 (2003). "Adhesive-wood adhesives for non-structural applications.

Determination of tensile-shear strength of lap joints," European Committee for Standardization, Brussels, Belgium.

Esteves, B., Domingos, I., Velez Marques, A., Nunes, L., and Pereira, H. (2006). "Variation of dimensional stability and durability of eucalypt wood by heat treatment," in: Proceeding ECOWOOD 2006, Porto, Portugal.

Finnish ThermoWood Association (2003). ThermoWood Handbook, Helsinki, Finland.

Gfeller, B., Zanetti, M., Properzi, M., Pizzi, A., Pichelin, F., Lehmann, M., and Delmotte, L. (2003). "Wood bonding by mechanically-induced in situ welding of polymeric structural wood constituents," J. Adhesion Sci. Technol. 17, 1425-1590. DOI: 10.1002/app. 13648

Goring, D. A. (1963). "Thermal softening of lignin, hemicellulose and cellulose," Pulp Pap. Mag. Can. 64(12), 517-527.

Horvath, B., Peralta, P., Frazier, C., and Peszlen, I. (2011). "Thermal softening of transgenic aspen," BioResources 6(2), 2125-2134.

International ThermoWood Association (2019). "International ThermoWood Association," (http://www.thermowood.fi.), Accessed November 18, 2019.

Jämsä, S., and Viitaniemi, P. (2001). "Heat treatment of wood: Better durability without chemicals," in: Review on Heat Treatments of Wood, Proceedings of Special Seminar of COST Action E22, Antibes, France. 
Mahnert, K. C., Adamopoulos, S., Koch, G., and Militz, H. (2013). “Topochemistry of heat- treated and N-methylol melamine modified wood of Koto (Pterygota macrocarpa K. Schum.) and Limba (Terminalia superba Engl. et Diels)," Holzforschung 67(2), 137-146. DOI: 10.1515/hf-2012-0017

Kollmann, F., and Fengel, D. (1965). "Changes in the chemical composition of wood due to thermal treatment," Holz als Roh-und Werkstoff 23(12), 461-468. DOI: 10.1007/s00107-004-0532-8

Omrani, P., Mansouri, H. R., Pizzi, A., and Masson. E. (2010). "Influence of grain direction and pre-heating on linear wood welding," Eur. J. Wood Prod. 68,113-114. DOI: $10.1007 / \mathrm{s} 00107-009-0349-6$

Sandberg, D., and Kutnar, A. (2016). "Thermally modified timber: Recent developments in Europe and North America," Wood Fiber Sci. 48, 28-39. DOI: 10.3832/ifor2380010

Shepp, L. A., and Logan, B. F. (1974) "The Fourier reconstruction of a head section," IEEE Trans. Nucl. Sci. 21(3), 21-43. DOI: 10.1109/TNS.1974.6499235

Stamm, A.J. (1956). "Thermal degradation of wood and cellulose," Ind. Eng. Chem. 48(3), 413-417.

Stamm, A. J. (1964). Wood and Cellulose Science, Ronald Press, New York.

Tiemann, H. D. (1906). Effect of Different Methods of Drying on the Strength of Wood. Lumber World, U.S. Department of Agriculture, Washington, D.C.

Vaziri, M., Lindgren, O., and Pizzi, A. (2012). "Optimization of tensile-shear strength for linear welded Scots pine," J. Adhesion Sci. Technol. 26(1-3), 109-119. DOI: 10.1163/016942411X569327

Vaziri, M., Karlsson, O., and Sandberg, D. (2019). "Wetting characteristic of welded wood. Part 1. Determination of apparent contact angle, swelling, and liquid sorption," Holzforschung. DOI: 10.1515/hf-2019-0308

Vaziri, M., Abrahamsson, L., Hagman, O., and Sandberg, D. (2020). "Welding of wood in the presence of wollastonite," BioResources 15(1), 1617-1628. DOI: 10.15376/biores.15.1.1617-1628

Zigon, J., Pizzi, A., Zhang, H., Sega, B., Cop, M., and Sernek, M. (2015). “The influence of heat and chemical treatments of beech wood on the shear strength of welded and UF bonded specimens," Eur. J. Wood Prod. 73,685-687. DOI: 10.1007/s00107-0150930-0

Živković, V., Prša, I., Turkulin, H., Sinković, T., and Jirouš-Rajković, V. (2008). "Dimensional stability of heat treated wood floorings," Drvna Industrija 59(2), 6573.

Article submitted: November 25, 2020; Peer review completed: February 21, 2021; Revised version received and accepted: March 7, 2021; Published: March 11, 2021. DOI: 10.15376/biores.16.2.3224-3234 